\title{
Key drivers of microbial abundance, activity, and diversity in karst spring waters across an altitudinal gradient in Slovenia
}

\author{
Maja Opalički Slabe ${ }^{1,2, *}$, Tjaša Danevčič ${ }^{3}$, Katrin $\mathrm{Hug}^{4}$, Lucas Fillinger ${ }^{5}$, \\ Ines Mandić-Mulec ${ }^{3}$, Christian Griebler ${ }^{4,5}$, Anton Brancelj ${ }^{1,2}$ \\ ${ }^{1}$ National Institute of Biology, Department of Organisms and Ecosystems Research, 1000 Ljubljana, Slovenia \\ ${ }^{2}$ University of Nova Gorica, Graduate School, Environmental Sciences, 5000 Nova Gorica, Slovenia \\ ${ }^{3}$ University of Ljubljana, Biotechnical Faculty, Department of Food Science and Technology, Chair of Microbiology, \\ 1000 Ljubljana, Slovenia \\ ${ }^{4}$ Helmholtz Zentrum München, German Research Centre for Environmental Health, Institute of Groundwater Ecology, \\ 85764 Neuherberg, Germany \\ ${ }^{5}$ University of Vienna, Department of Functional and Evolutionary Ecology, 1090 Vienna, Austria
}

\begin{abstract}
In aquatic ecosystems, the biomass, activity and composition of microorganisms are determined to a large extent by local and regional environmental conditions. While karst aquifers are an important source for drinking water, the ecology of microbial communities in karst waters has hardly been studied. This study examined the regional variations and seasonal dynamics of microbial communities in pristine karst spring waters of Slovenia (Central Europe). Fifteen springs distributed across 5 eco-regions exhibiting a strong altitudinal gradient were sampled 4 times a year. Evaluation of the microbial communities included quantification of prokaryotic biomass via total cell counts and microbial activity estimated via measurements of electron transport system activity. The taxonomic structure of the bacterial communities was analysed by terminal restriction fragment length polymorphism fingerprinting. Biological measures were complemented by a set of physico-chemical parameters, including dissolved organic carbon, nutrients, major ions, temperature, electrical conductivity, $\mathrm{pH}$, and dissolved oxygen. Bacterial community structure differed significantly with seasons and eco-regions, with the latter causing greater variation. While the overall power of the environmental variable tested was a moderate factor $(15 \%)$ in explaining the variability in microbial community structure, catchment altitude was a key determinant. Prokaryotic cell density and microbial activity in spring water decreased with an increase in catchment altitude and were significantly positively correlated. For a better understanding of karst ecosystems and the ecosystem service of water purification, future investigation should address karst microbial communities at a higher phylogenetic and functional resolution.
\end{abstract}

KEY WORDS: Karst springs $\cdot$ Microbial diversity $\cdot$ Total cell counts $\cdot$ TCC $\cdot$ Electron transport system activity $\cdot$ ETSA $\cdot$ Terminal restriction fragment length polymorphism $\cdot$ T-RFLP

\section{INTRODUCTION}

Groundwater from karst aquifers supplies a quarter of the world's population with drinking water (Smart \& Worthington 2004a). At the same time, karst aquifers

\footnotetext{
${ }^{*}$ Corresponding author: maja.opalicki.slabe@nib.si
}

are unique ecosystems that are populated by a vast variety of microorganisms (Farnleitner et al. 2005, Griebler \& Lueders 2009) and groundwater meiofauna (Botosaneanu 1986, Danielopol et al. 2000, Gibert \& Culver 2009). These organisms provide essential eco-

() The authors 2021. Open Access under Creative Commons by Attribution Licence. Use, distribution and reproduction are unrestricted. Authors and original publication must be credited. 
system services such as water purification processes through the mineralisation of carbon and other nutrients (Griebler \& Avramov 2015). In particular, microbes are crucial in maintaining good chemical and hygienic groundwater quality (Griebler \& Avramov 2015, Feichtmayer et al. 2017, Griebler et al. 2019).

In Slovenia, about half of the country is covered by karst (Gams 1974), and karst water contributes up to $50 \%$ of the drinking water supply (Brečko Grubar \& Plut 2001). Karst springs are 'open windows' into the karst systems, which are otherwise difficult to access for research. Microbial communities are discharged with karst water to the surface, making them accessible for detailed analysis (Smart \& Worthington 2004b). To date, karst springs, even when used to supply drinking water, are regularly monitored only for (1) the quantity of discharge, (2) basic physico-chemical parameters (temperature, $\mathrm{pH}$, electrical conductivity $[\mathrm{EC}]$, dissolved oxygen [DO], major ions, and nutrients), (3) specific groups of chemicals (e.g. pesticides), and (4) the presence of indicators for faecal contamination (E. coli and coliform bacteria). No measures are routinely taken to monitor ecological parameters, including the abundance, biomass, activity, and diversity of microbial communities (Griebler et al. 2010, Korbel \& Hose 2011). As a consequence, our knowledge about the microbiology of karst aquifers and springs is rather limited (Farnleitner et al. 2005, Pronk et al. 2009, Wilhartitz et al. 2009, Shabarova et al. 2014), including the Slovenian karst.

Groundwater ecosystems have classically been considered to be stable environments that undergo relatively little variations in physico-chemical conditions over time compared to other ecosystems on the land surface (Goldscheider et al. 2006, Griebler \& Lueders 2009). Consequently, compared to microbial communities in other aquatic or terrestrial ecosystems (Comte et al. 2017, Langenheder \& Lindström 2019), the mechanisms that shape microbial community structure across space and time in groundwater have been understudied (see e.g. Fillinger et al. 2019, Zelaya et al. 2019, Yan et al. 2020). However, more recent studies on single aquifers, including alluvial (Lin et al. 2012, Zhou et al. 2012, Graham et al. 2016, 2017, Zelaya et al. 2019), fractured (Yan et al. 2020), and karst aquifers (Shabarova et al. 2013, 2014, Savio et al. 2019), showed that groundwater microbial communities can indeed display considerable temporal variation in response to changes in hydrochemistry, composition of the carbon pool, and organic matter (OM) availability, as well as hydrodynamics caused by changes in groundwater discharge. Changes in discharge can be especially important for the temporal variation in microbial pattern, as they affect the dispersal of taxa across aquifer zones via passive transport and can partially override the effect of physico-chemical conditions on microbial community composition (Yan et al. 2020). In karst ecosystems, this can be of particular importance, because in times of high discharge, microbial taxa can be spread across karst pools that are otherwise hydrologically separated over longer time periods. During periods of low discharge and hydrological separation, divergent microbial communities may develop within individual pools due to site-specific changes in hydrochemistry, quantity and quality of the OM, and priority effects (Shabarova et al. 2013, 2014, Svoboda et al. 2018). Studies comparing microbial communities across aquifers are so far rare (Ben Maamar et al. 2015, Danczak et al. 2018). However, Fillinger et al. (2019) demonstrated that differences in microbial community composition between aquifers could be explained in large part by differences in environmental conditions, and to a lesser extent by limited exchange of taxa across aquifers via dispersal. To this point, there are no studies that have compared temporal variations in microbial communities in groundwater across multiple aquifers - which would be an important step in identifing general mechanisms underlying these variations.

In this study, we investigated spatio-temporal dynamics of prokaryotic cell numbers, microbial respiratory activity, and bacterial community structure from 15 karst springs that belong to geographically distinct aquifers in 5 eco-regions of Slovenia (Central Europe). Although similar in geology (a mixture of limestone and dolomite), the springs in the selected eco-regions differ in mean altitude of the catchment and altitude of spring outlets, catchment sizes, as well as mean annual precipitation and air temperature. We hypothesized that (1) assuming a significant influence of environmental conditions on groundwater microbial community structure (Stegen et al. 2013, Graham et al. 2016, 2017, Fillinger et al. 2019, Zelaya et al. 2019, Yan et al. 2020), the bacterial communities within eco-regions and seasons would be more similar to each other than between eco-regions and seasons, (2) regional differences would have a greater impact on bacterial community structure than seasonality; and (3) microbial abundance and activity in spring water would decrease with higher altitudes (Wilhelm et al. 2015). To account for seasonal dynamics, all springs were sampled once in autumn, winter, spring, and summer between October 2014 and August 2015. To elucidate the driving forces involved in shaping bacterial communities in 
karst spring waters, we applied a set of simple measures, i.e. total prokaryotic cell counts (TCC), microbial respiratory activity (as electron transport system activity, ETSA), and assessment of microbial community structure based on terminal restriction fragment length polymorphism (T-RFLP) fingerprinting of $16 \mathrm{~S}$ rRNA gene amplicons. In addition, a comprehensive set of physico-chemical parameters of the spring water was determined at each sampling event.

\section{MATERIALS AND METHODS}

\subsection{Study sites}

We investigated 15 karst springs within 5 ecoregions in Slovenia (Central Europe) (Fig. 1). Two regions belong to the Alpine karst (the KamnikSavinja-Karavanke Alps and the Julian Alps), 2 regions to the high Dinaric karst (the Trnovo plateau and the Ljubljanica karst), and one region to the low Dinaric karst (the Dolenjska karst). In each ecoregion, 3 hydrologically discrete springs were selected for sampling. Their main hydrogeological characteristics were previously studied by Mezga (2014) and Cerar (2016) and are summarized in Table 1.

\subsection{Sample collection}

We conducted 4 sampling campaigns between October 2014 and August 2015, once per season (Octo- ber 2014, February 2015, May 2015, and August 2015). Sampling was performed only in dry weather conditions, when no or minimal precipitation occurred $7 \mathrm{~d}$ before, to avoid sampling predominantly surface-derived microorganisms washed out from the upper soil layers. Sampling campaigns were planned based on data from the nearest hydrological station to each spring, which recorded river discharge and precipitation (ARSO 2014a,b).

We filled three 51 sterile glass bottles (sterilised at $121^{\circ} \mathrm{C}$ for $15 \mathrm{~min}$, rinsed with $96 \%$ ethanol, and then thoroughly rinsed on-site with spring water before sample collection) per sampling site with spring water for microbial analyses. We carefully filled bottles to avoid contamination. Samples were transported to the laboratory within $8 \mathrm{~h}$ (cooled in the dark) and stored at $4^{\circ} \mathrm{C}$ until further processing.

\subsection{Physico-chemical measurements}

Spring water temperature $\left(T_{\text {water }}\right), \mathrm{pH}, \mathrm{EC}$, and DO concentration were measured using field sensors (WTW Multi set 3430) on-site. For further chemical analyses, we filtered spring water on-site using 0.45 and $0.22 \mu \mathrm{m}$ membrane filters (Sartorius Minisart ${ }^{\circledR}$ NML Syringe Filters 16555-K and 16534-K, respectively) and stored the samples in $50 \mathrm{ml}$ PVC plastic bottles. Samples were transferred cooled and in the dark into the laboratory and stored at $4{ }^{\circ} \mathrm{C}$ until analyses. We performed analyses within $24 \mathrm{~h}$ after sampling.

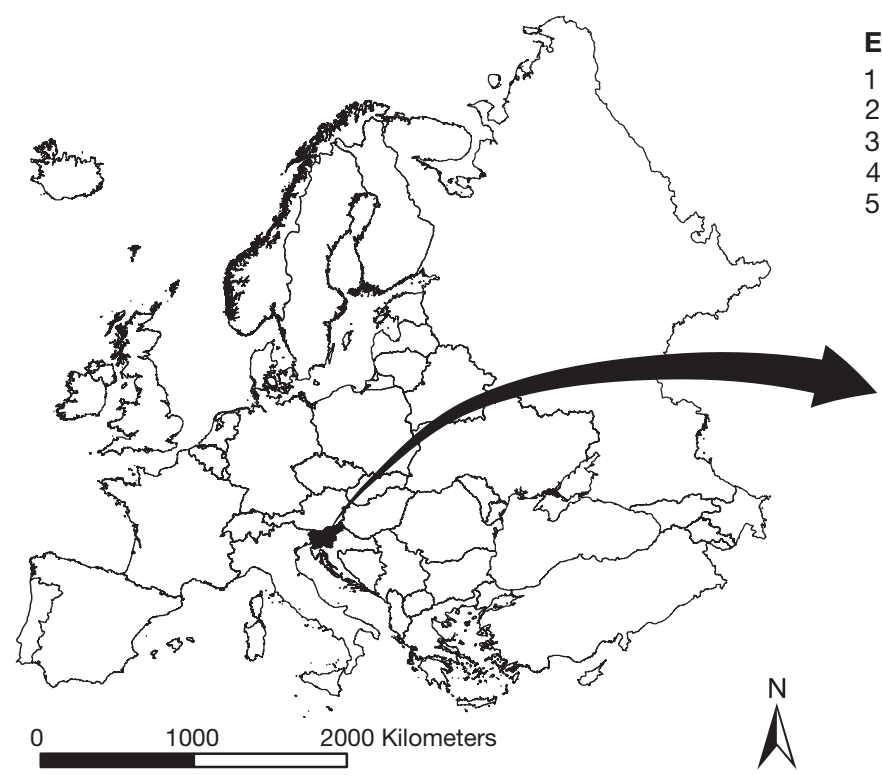

Eco-regions

1 - the Kamnik-Savinja-Karavanke Alps

2 - the Julian Alps

3 - the Trnovo plateau

4 - the Ljubljanica karst

5 - the Dolenjska karst

\section{Karst regions}

$1 \& 2$ - the Alpine karst $3 \& 4$ - the high Dinaric karst 5 - the low Dinaric karst

Fig. 1. Europe (left) and Slovenia (right) with studied karst eco-regions (1 to 5) and springs (black points) 
Table 1. Main characteristics of studied springs from 5 karst eco-regions in Slovenia (data extracted from Mezga 2014 and Cerar 2016)

\begin{tabular}{|c|c|c|c|c|c|c|c|}
\hline Eco-region & Spring & $\begin{array}{l}\text { Altitude of } \\
\text { spring } \\
\text { outlet } \\
\text { (m) }\end{array}$ & $\begin{array}{l}\text { Mean } \\
\text { altitude of } \\
\text { catchment } \\
\quad(\mathrm{m})\end{array}$ & $\begin{array}{c}\text { Size of } \\
\text { catchment } \\
\text { area }\left(\mathrm{km}^{2}\right)\end{array}$ & $\begin{array}{l}\text { Mean annual } \\
\text { amount of } \\
\text { precipitation } \\
(1971-2000) \\
(\mathrm{mm})\end{array}$ & $\begin{array}{c}\text { Mean annual } \\
\text { air temperature } \\
(1971-2000) \\
\left({ }^{\circ} \mathrm{C}\right)\end{array}$ & $\begin{array}{l}\text { Litho- } \\
\text { logical } \\
\text { unit }\end{array}$ \\
\hline $\begin{array}{l}\text { 1. The Kamnik-Savinja- } \\
\text { Karavanke Alps }\end{array}$ & $\begin{array}{c}\text { Mošenik } \\
\text { Kamniška Bistrica } \\
\text { Črna }\end{array}$ & $\begin{array}{l}840 \\
592 \\
744\end{array}$ & $\begin{array}{l}1360.4 \\
1683.5 \\
1361.8\end{array}$ & $\begin{array}{c}2.11 \\
22.12 \\
22.01\end{array}$ & $\begin{array}{l}2178 \\
2208 \\
2077\end{array}$ & $\begin{array}{l}4.3 \\
3.7 \\
4.5\end{array}$ & $\begin{array}{l}\text { Limestone } \\
\text { Limestone } \\
\text { Dolomite }\end{array}$ \\
\hline 2. The Julian Alps & $\begin{array}{l}\text { Krajcarica } \\
\text { Lipnik } \\
\text { Lipnica }\end{array}$ & $\begin{array}{l}706 \\
648 \\
494\end{array}$ & $\begin{array}{c}1310.4 \\
1444.4 \\
784.8\end{array}$ & $\begin{array}{c}0.87 \\
20.39 \\
21.26\end{array}$ & $\begin{array}{l}2537 \\
2302 \\
2278\end{array}$ & $\begin{array}{l}5.2 \\
4.8 \\
5.2\end{array}$ & $\begin{array}{l}\text { Limestone } \\
\text { Dolomite } \\
\text { Limestone }\end{array}$ \\
\hline 3. The Trnovo plateau & $\begin{array}{l}\text { Podroteja } \\
\text { Hubelj } \\
\text { Vipava }\end{array}$ & $\begin{array}{l}330 \\
229 \\
103\end{array}$ & $\begin{array}{c}602.3 \\
1009.6 \\
809.9\end{array}$ & $\begin{array}{l}51.05 \\
52.16 \\
100.9\end{array}$ & $\begin{array}{l}2300 \\
2483 \\
2276\end{array}$ & $\begin{array}{l}8.2 \\
6.9 \\
7.9\end{array}$ & $\begin{array}{l}\text { Dolomite } \\
\text { Limestone } \\
\text { Limestone }\end{array}$ \\
\hline 4. The Ljubljanica karst & $\begin{array}{l}\text { Močilnik } \\
\text { Malenščica } \\
\text { Korentan }\end{array}$ & $\begin{array}{l}295 \\
450 \\
537\end{array}$ & $\begin{array}{l}672.8 \\
595.2 \\
572.0\end{array}$ & $\begin{array}{c}1054 \\
22.81 \\
6.34\end{array}$ & $\begin{array}{l}1941 \\
1962 \\
1900\end{array}$ & $\begin{array}{l}7.9 \\
8.6 \\
9.0\end{array}$ & $\begin{array}{l}\text { Limestone } \\
\text { Limestone } \\
\text { Limestone }\end{array}$ \\
\hline 5. The Dolenjska karst & $\begin{array}{c}\text { Poltarica } \\
\text { Tominčev izvir } \\
\text { Radeščica }\end{array}$ & $\begin{array}{l}272 \\
173 \\
176\end{array}$ & $\begin{array}{l}420.6 \\
517.2 \\
580.0\end{array}$ & $\begin{array}{l}261.3 \\
278.2 \\
194.5\end{array}$ & $\begin{array}{l}1422 \\
1524 \\
1630\end{array}$ & $\begin{array}{l}9.0 \\
8.6 \\
8.0\end{array}$ & $\begin{array}{l}\text { Limestone } \\
\text { Limestone } \\
\text { Limestone }\end{array}$ \\
\hline
\end{tabular}

Major cations $\left(\mathrm{Ca}^{2+}, \mathrm{Mg}^{2+}, \mathrm{Na}^{+}, \mathrm{K}^{+}, \mathrm{NH}_{4}{ }^{+}\right)$and anions $\left(\mathrm{SO}_{4}{ }^{2-}, \mathrm{NO}_{3}{ }^{-}, \mathrm{NO}^{2-}, \mathrm{Cl}^{-}\right)$were determined by ion chromatography (Metrohm, 761 Compact IC), and dissolved organic carbon (DOC) as non-purgeable organic carbon in a total organic carbon analyzer (Analytik Jena Multi C/N 3100).

\subsection{Analyses of prokaryotic cell abundances}

To determine microbial abundance, we measured TCC by flow cytometry, as described by Hammes et al. (2008). In the laboratory, water samples $(50 \mathrm{ml})$ were fixed with formaldehyde $(3.6 \%$ final concentration) in triplicate and stored at $4^{\circ} \mathrm{C}$ until further analyses. A sample volume of $500 \mu \mathrm{l}$ was stained with $6 \mu \mathrm{l}$ SYBR-Green I working solution $(10 \mu \mathrm{l}$ SYBR Green I nucleic acid stain [10 000×, InvitrogenThermo Scientific] and $990 \mu$ Tris buffer [10 mM; $\mathrm{pH}$ 8.0]), immediately mixed on a vortex, and incubated for $13 \mathrm{~min}$ at $37^{\circ} \mathrm{C}$ in the dark before adding $100 \mu \mathrm{l}$ of a reference beads solution (Trucount Tubes, Becton Dickinson) as an internal standard. We counted stained cells in a CYTOMICS FC 500 Flow Cytometer (Beckman Coulter) using a $488 \mathrm{~nm}$ blue light laser for excitation (Bayer et al. 2016). Cells were distinguished from inorganic and organic particles based on side scatter and fluorescence measured at $569 \pm 15 \mathrm{~nm}( \pm \mathrm{SD})$. To obtain technical replicates, each of the triplicate samples was measured twice.

\subsection{Analyses of microbial respiratory activity}

We measured microbial ETSA according to Packard (1971) with modifications made by G.-Tóth (1999). ETSA is a measure of the metabolic activity of the microorganisms, which is reflected in the transport of electrons through the respiratory chain in the plasma membrane. We collected microbial biomass from 11 of spring water on a sterile $0.2 \mu \mathrm{m}$ cellulose nitrate filter (Sartorius Cellulose Nitrate Membrane Filter). Filters were stored at $-80^{\circ} \mathrm{C}$ until analysis. Filters were homogenised in $3 \mathrm{ml}$ of ice-cold homogenisation buffer (0.1 M sodium phosphate buffer at $\mathrm{pH} 8.4$; $75 \mu \mathrm{M} \mathrm{MgSO}_{4} ; 0.15 \% \mathrm{w} / \mathrm{v}$ polyvinyl pyrrolidone; $0.2 \% \mathrm{v} / \mathrm{v}$ Triton-X-100) with an ultrasonic homogeniser (Cole-Parmer, 4710 Series) for $3 \mathrm{~min}$. Samples were centrifuged for $4 \mathrm{~min}$ at $0^{\circ} \mathrm{C}$ and $8500 \times g$ (2K15, Sigma). A $1.5 \mathrm{ml}$ aliquot of substrate solution (0.1 $\mathrm{M}$ sodium phosphate buffer at $\mathrm{pH} 8.4 ; 1.7 \mathrm{mM}$ $\mathrm{NADH} ; 0.25 \mathrm{mM}$ NADPH; $0.2 \% \mathrm{v} / \mathrm{v}$ Triton-X-100) and $0.5 \mathrm{ml}$ of reagent solution $(2.5 \mathrm{mM} \mathrm{2-(p-iodo-}$ phenyl)-3-(p-nitrophenyl)-5-phenyl tetrazolium chloride [INT]) were added to $0.5 \mathrm{ml}$ of supernatant from the homogenate and incubated for $45 \mathrm{~min}$ at $20^{\circ} \mathrm{C}$. The reaction was stopped by adding $0.5 \mathrm{ml}$ of stop- 
ping solution (formalin: $\mathrm{H}_{3} \mathrm{PO}_{4}=1: 1 \mathrm{v} / \mathrm{v}$ ). For control, blanks (substrate and reagent solution) were incubated and stopped as in the samples, and then $0.5 \mathrm{ml}$ of supernatant from the homogenate was added. Formazan production was measured spectrophotometrically (WTW, PhotoLab Spektral) from the absorbance of the sample at $490 \mathrm{~nm}$ against the blank. The ETSA was measured as the rate of tetrazolium dye reduction and expressed in $\mu \mathrm{l}$ of oxygen $\mathrm{l}^{-1} \mathrm{~h}^{-1}$, as described by Kenner \& Ahmed (1975). We measured all samples in triplicate.

\subsection{DNA extraction, amplification of bacterial 16S rRNA gene, and T-RFLP analyses}

We used T-RFLP to analyse microbial community structure. For each sampling site, we collected microbial cells from 21 of spring water (in triplicate) on sterile $0.22 \mu \mathrm{m}$ filters by vacuum filtration (Corning $250 \mathrm{ml}$ Vacuum Filter/Storage Bottle System with Cellulose Acetate Membrane). Afterwards, we stored the filters at $-80^{\circ} \mathrm{C}$ until further processing.

We extracted bacterial DNA from one-half of each filter (corresponding to $1 \mathrm{l}$ of filtered water) using the PowerSoil ${ }^{\circledR}$ DNA Isolation Kit according to manufacturer's instructions (MO BIO Laboratories). The DNA was used as a template for PCR amplification of 16S rRNA gene fragments using universal bacterial primers $27 \mathrm{f}$ (FAM-5'-AGA GTT TGA TCC TGG CTC AG-3') labelled with 6-FAM (6-Carboxyfluorescein) and 927r (5'-CCG TCA ATT CCT TTR AGT TT-3'), which are used to study bacterial community structure from different environments (Heuer \& Smalla 1997). PCR was performed on 3 independent samples per spring and time point. We performed amplification in $50 \mu \mathrm{l}$ reaction mixtures, containing $2 \mu \mathrm{l}$ of DNA template, $10 \mu \mathrm{l}$ of $5 \times$ PCR GoTaq ${ }^{\circledR}$ Flexi Buffer (Promega), $4 \mathrm{\mu l}$ of $25 \mathrm{mM} \mathrm{MgCl} \mathrm{m}_{2}$ solution (Promega), $0.5 \mu \mathrm{l}$ of $100 \%$ deionised formamide, $0.5 \mu \mathrm{l}$ of $20 \mathrm{mg} \mathrm{ml}^{-1}$ nonacetylated BSA, $1 \mu \mathrm{l}$ of $10 \mathrm{mM}$ deoxynucleotide triphosphate (dNTP), $1 \mu \mathrm{l}$ of a $10 \mu \mathrm{M}$ of each primer, $0.8 \mu \mathrm{l}$ of 5 units $\mu \mathrm{l}^{-1}$ GoTaq $^{\circledR}$ DNA Polymerase (Promega), and $29.2 \mu \mathrm{l}$ of nuclease-free Milli-Q water. The PCR was performed in a TProfessional Basic Thermocycler (Biometra) with the following conditions: initial denaturation for $5 \mathrm{~min}$ at $94^{\circ} \mathrm{C}$ followed by $30-35$ cycles (depending on DNA template concentration) with a denaturation for $1 \mathrm{~min}$ at $94^{\circ} \mathrm{C}$, annealing for $1 \mathrm{~min}$ at $53^{\circ} \mathrm{C}$ and an extension for $1.5 \mathrm{~min}$ at $72^{\circ} \mathrm{C}$, and the final extension for $10 \mathrm{~min}$ at $72^{\circ} \mathrm{C}$. PCR products were checked on a $0.8 \%(\mathrm{w} / \mathrm{v})$ agarose gel and stained with GelRed (Nucleic Acid Stain, Biotium).
We purified PCR products using the Pure Link ${ }^{\circledR}$ PCR Purification Kit (Invitrogen) according to the manufacturer's instructions and then quantified on a NanoDrop ND-1000 spectrophotometer (Thermo Scientific). Purified PCR products (100 ng) were digested with FastDigest ${ }^{\mathrm{TM}}$ enzyme AluI (Thermo Scientific) in a $30 \mu \mathrm{l}$ reaction mixture according to the manufacturer's instructions and purified by ethanol precipitation. Briefly, samples were mixed with $3 \mu \mathrm{l}$ of $3 \mathrm{M}$ sodium acetate ( $\mathrm{pH}$ 5.2) and $66 \mu \mathrm{l}$ of $96 \%(\mathrm{v} / \mathrm{v})$ ethanol and incubated for $30 \mathrm{~min}$ on ice. After incubation, samples were centrifuged at $15000 \times g$ and $4^{\circ} \mathrm{C}$ for $30 \mathrm{~min}$. Supernatants were discarded, $500 \mu \mathrm{l}$ cold $70 \%$ (v/v) ethanol was added, and samples were immediately centrifuged at $15000 \times g$ and $4^{\circ} \mathrm{C}$ for $10 \mathrm{~min}$. Supernatants were discarded, and samples were air-dried and stored at $-20^{\circ} \mathrm{C}$ for further analyses.

For T-RFLP analysis, digested and purified products were mixed with $3 \mu \mathrm{l}$ of sterile Milli-Q water, $0.4 \mu \mathrm{l}$ of GeneScan ${ }^{\mathrm{TM}} 500 \mathrm{ROX}^{\mathrm{TM}}$ Size Standard (Applied Biosystems), and $10 \mu \mathrm{l}$ of deionised formamide. Prior to fragment analysis, DNA samples were denatured at $95^{\circ} \mathrm{C}$ for $4 \mathrm{~min}$ and then frozen on ice. The T-RFLP analyses were performed with an automated 3130xl Genetic Analyzer (Applied Biosystems).

\subsection{Data analyses}

We used multi-class linear discriminant analysis (LDA) to separate eco-regions in classes based on physico-chemical data, with the program Paleontological Statistics (PAST) version 3.16 (Hammer et al. 2001). Before analysis, physico-chemical parameters were $\log (x+1)$ transformed to approximate normal data distribution. We applied the Kruskal-Wallis nonparametric test to test for differences in physicochemical parameters between seasons and ecoregions, using SPSS version 20.0 (IBM Corporation 2011).

Raw T-RFLP data were imported into the program Peak Scanner version 1.0 (Applied Biosystems), which identifies peaks and fragment sizes. In the analyses, DNA fragments smaller than 50 and larger than $500 \mathrm{bp}$ were removed and the size standard GS500 was used. Data exported from Peak Scanner were imported into the web based tool T-Align (Smith et al. 2005), where multiple T-RFLP profiles could be aligned and compared. Relative abundances of T-RFs were used to calculate differences in community structure between samples ( $\beta$-diversity) based on Bray-Curtis dissimilarity, using PAST. Differences 
in community structure between season and ecoregion were visualized by non-metric multi-dimensional scaling (nMDS). Prior to the nMDS analysis, data were normalized and square root transformed. ANOSIM with 9999 randomizations was conducted to determine significant differences between seasons and eco-regions, using Bray-Curtis dissimilarity in PAST.

We used canonical correspondence analysis (CCA) to relate bacterial communities to the environmental variables and to test how much variability they explain. Before the analysis, the output data from TAlign were normalised and square rooted and environmental variables were $\log (x+1)$ transformed. The CCA forward selection method was used to reduce the number of explanatory variables in the canonical ordination model. The analyses were conducted in CANOCO 5 (ter Braak \& Šmilauer 2012).

The TCC and ETSA data were tested for normal distribution and separated to eco-regions and seasons. Data were $\log (x+1)$ transformed, and univariate ANOVA with post-hoc Tukey test for multiple pairwise comparisons within seasons and eco-regions were performed. The analyses and the box-andwhisker plots were done in SPSS.

In addition, Spearman's rank-order correlation and hierarchical multiple regression analyses with curve fitting were performed in SPSS to test for changes in prokaryotic cell densities and microbial respiratory activities, respectively with increasing altitude of the catchment. Before regression analyses, data were $\log (x+1)$ transformed to approximate normal distribution.

\section{RESULTS}

\subsection{Differences in physico-chemical parameters between eco-regions and seasons}

LDA revealed that karst spring waters from the different eco-regions generally showed distinct physicochemical parameters, except for Ljubljanica karst and Dolenjska karst, which exhibited similar characteristics to one another (Fig. 2; a detailed overview of individual parameters is shown in Table 2). Nitrate $\left(\mathrm{NO}_{3}{ }^{-}\right)$concentrations explained most of the variance on the first axis, which separated the Alps from other eco-regions, indicating that $\mathrm{NO}_{3}{ }^{-}$ concentrations decrease with higher altitudes. Conversely, concentrations of major ions $\left(\mathrm{Cl}^{-}, \mathrm{Na}^{+}, \mathrm{Ca}^{2+}\right)$ and DOC, as well as EC, separated eco-regions on the second axis. We found the highest concentrations of major ions in the Julian Alps compared to the Kamnik-Savinja-Karavanke Alps, and in the Ljubljanica and Dolenjska karst compared to the Trnovo plateau. While statistically significant differences between eco-regions were detected for all individual physico-chemical parameters (pooling all seasons together) (Kruskal-Wallis test; all p < 0.05), we only revealed significant differences between seasons for DOC $(\mathrm{p}<0.001)$ and $\mathrm{pH}(\mathrm{p}=0.001)$ when pooling all regions together.

\subsection{Spatial-temporal variations in bacterial community structure}

The nMDS and ANOSIM analyses indicated that the structure of the bacterial communities changed with seasons in each eco-region (Fig. 3). The largest seasonal changes in bacterial community structure occurred in the Dolenjska karst and the smallest in the Trnovo plateau (1-way ANOSIM; Dolenjska karst: $\mathrm{R}=0.688, \mathrm{p}<0.001$; Trnovo plateau: $\mathrm{R}=0.364$, $\mathrm{p}<0.001)$. Bacterial community structures also var-

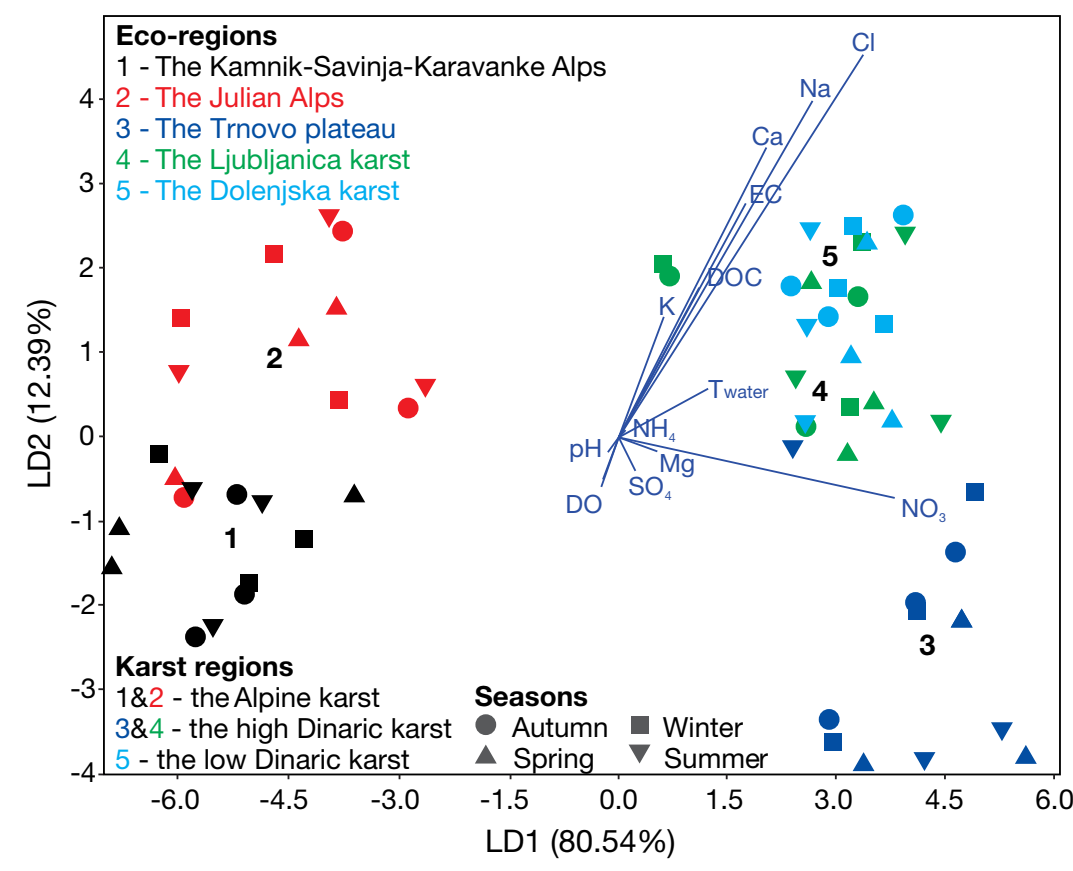

Fig. 2. Linear discriminant analysis (LDA) biplot of physico-chemical water parameters combined for 15 springs from 5 karst eco-regions in Slovenia, sampled across 4 seasons (autumn, winter, spring, summer) in the period 2014-2015 
ied regionally within seasons, despite a certain degree of overlap of samples from different regions, mainly between the Ljubljanica and Dolenjska karst eco-regions (Fig. 4). Results of the 1-way ANOSIMs also showed that the most prominent difference between bacterial community structures across ecoregions occurred in autumn $(R=0.645, p<0.001)$ and the least prominent in winter $(\mathrm{R}=0.426, \mathrm{p}<0.001)$. In summary, the comparison between seasons and ecoregions with the 2-way ANOSIM indicated a greater variation in bacterial community structure between eco-regions ( $\mathrm{R}=0.543, \mathrm{p}<0.001)$ compared to seasonal variations $(R=0.440, p<0.001)$.

\subsection{Relationship between bacterial community structure and environmental parameters}

CCA was used to further explore the effects of changes in physico-chemical parameters of the spring water on the observed differences and dynamics in bacterial community structure between seasons and eco-regions (Fig. 5). Environmental variables explained $14.8 \%$ of the variation in bacterial community structure (eigenvalue $1=0.247$, eigenvalue $2=$ 0.093 ) and total inertia was 3.789. The environmental variables with the strongest individual effect on bacterial community structure were the catchment altitude (6.1\% explained variation), sulphate concentration $(2.1 \%)$, oxygen concentration $(1.8 \%), \mathrm{NO}_{3}{ }^{-}$ concentration $(1.7 \%)$, precipitation within $7 \mathrm{~d}$ before sampling $(1.6 \%)$, and $\mathrm{pH}(1.5 \%)$. The altitude of the catchment together with the $\mathrm{NO}_{3}{ }^{-}$concentration disentangled samples from different eco-regions along the first CCA axis; the Kamnik-Savinja-Karavanke Alps and part of the Julian Alps, with the highest altitude and lowest $\mathrm{NO}_{3}{ }^{-}$concentrations, versus the Ljubljanica and Dolenjska karst on the opposite side of the axis representing a relatively lower altitude and higher $\mathrm{NO}_{3}{ }^{-}$concentrations. On the other hand, no separation of eco-regions was observed along the second CCA axis, which was mainly influenced by precipitation within $7 \mathrm{~d}$ before sampling and the sulphate concentration.

\subsection{Differences in prokaryotic abundance and microbial activity between eco-regions and seasons}

When evaluated across all seasons, the lowest TCC in spring water on average was detected in the KamnikSavinja-Karavanke Alps $\left(2.3 \times 10^{4} \pm 2.4 \times 10^{4} \mathrm{cells} \mathrm{ml}^{-1}\right)$, and the highest in the Dolenjska karst $\left(1.6 \times 10^{5} \pm\right.$

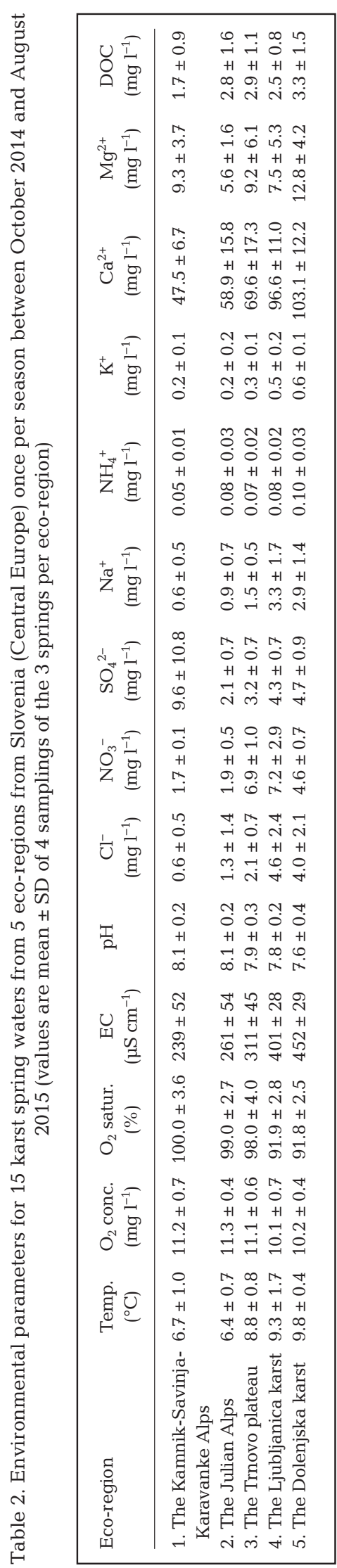


The Kamnik-Savinja-Karavanke Alps

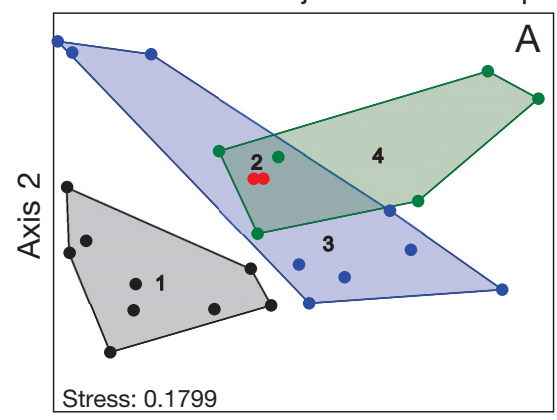

Axis 1

The Ljubljanica karst

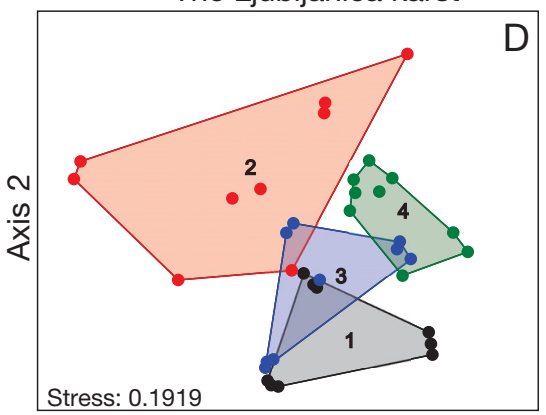

Axis 1

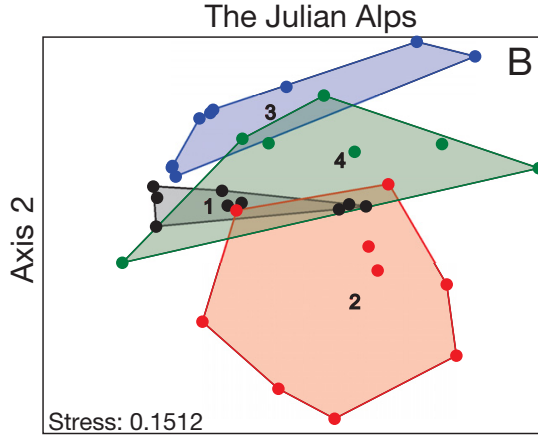

Axis 1

The Dolenjska karst

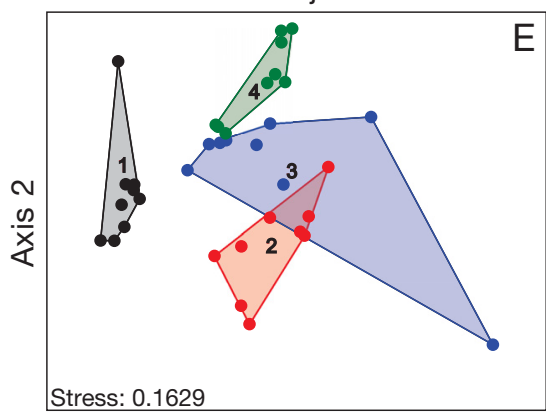

Axis 1

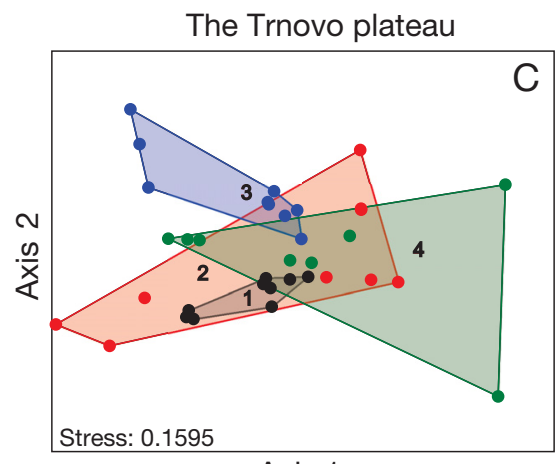

Axis 1
LEGEND:

1 - Autumn

2 - Winter

3 - Spring

4 - Summer

Fig. 3. Non-metric multi-dimensional scaling analyses based on Bray-Curtis similarities of bacterial community structure of 15 springs from 5 karst eco-regions in Slovenia sampled across seasons (autumn, winter, spring, and summer) in the period from October 2014 to August 2015. Each enclosed shape with 9 points represents 3 springs in triplicate (as some samples did not have enough DNA for analyses, there are fewer points in some frames)

$1.4 \times 10^{5}$ cells ml$^{-1}$ ), which represent the eco-regions with the highest and the lowest catchment altitude, respectively (detailed results in Table 3, Fig. 6). Significant differences for TCC were found between ecoregions (by average seasonal values; $\mathrm{ANOVA}_{;} F_{4,40}=$ 15.953, $\mathrm{p}<0.001$ ) and between seasons (by average regional values; $F_{3,40}=6.643, \mathrm{p}=0.001$ ). When tested in pairwise comparisons, TCC was neither statistically different between the Dolenjska and the Ljubljanica karst, nor between the Trnovo plateau and the Julian Alps considering values from all seasons (Tukey's post-hoc test; all $p>0.050$ ). Regarding differences between seasons, TCC values in winter were the most significantly different from TCC values in other seasons (Tukey's post-hoc test; all regions combined; all $\mathrm{p}<0.012$ ).

The seasonal average ETSA ranged from $0.185 \pm$ $0.096 \mathrm{\mu l} \mathrm{O}_{2} \mathrm{l}^{-1} \mathrm{~h}^{-1}$ in the Kamnik-Savinja-Karavanke Alps (eco-region with the highest catchment altitude) to $0.735 \pm 0.606 \mu \mathrm{O}_{2} \mathrm{l}^{-1} \mathrm{~h}^{-1}$ in the Dolenjska karst (eco-region with the lowest catchment altitude; detailed results in Table 4, Fig. 6). There were significant differences between eco-regions (ANOVA; $\left.F_{4,40}=13.681, \mathrm{p}<0.001\right)$ and seasons $\left(F_{3,40}=9.090\right.$, $\mathrm{p}<0.001)$. According to the Tukey's post-hoc test based on the ETSA values, eco-regions clustered into 2 groups (by combining all seasons): the KamnikSavinja-Karavanke Alps, the Julian Alps, with the Trnovo plateau; and the Ljubljanica and Dolenjska karst (all $\mathrm{p}>0.050$ ). The largest differences in ETSA among seasons (by combining all regions) were found between autumn and spring $(\mathrm{p}<0.001)$.

\subsection{Influence of catchment area characteristics on prokaryotic cell density and microbial respiratory activity}

The relationships between catchment area characteristics and prokaryotic cell density (i.e. TCC), microbial respiratory activity (i.e. ETSA) as well as DOC and $\mathrm{pH}$ were tested with Spearman's rankorder correlation analysis. Prokaryotic cell density and microbial respiratory activity were significantly correlated. For TCC, a significant negative correlation was found with the altitude of the catchment, and significant positive correlation with water temperature and DOC concentrations. Additionally, EC and concentration of $\mathrm{Ca}^{2+}$ ions were significantly positively correlated with TCC and ETSA and neg- 

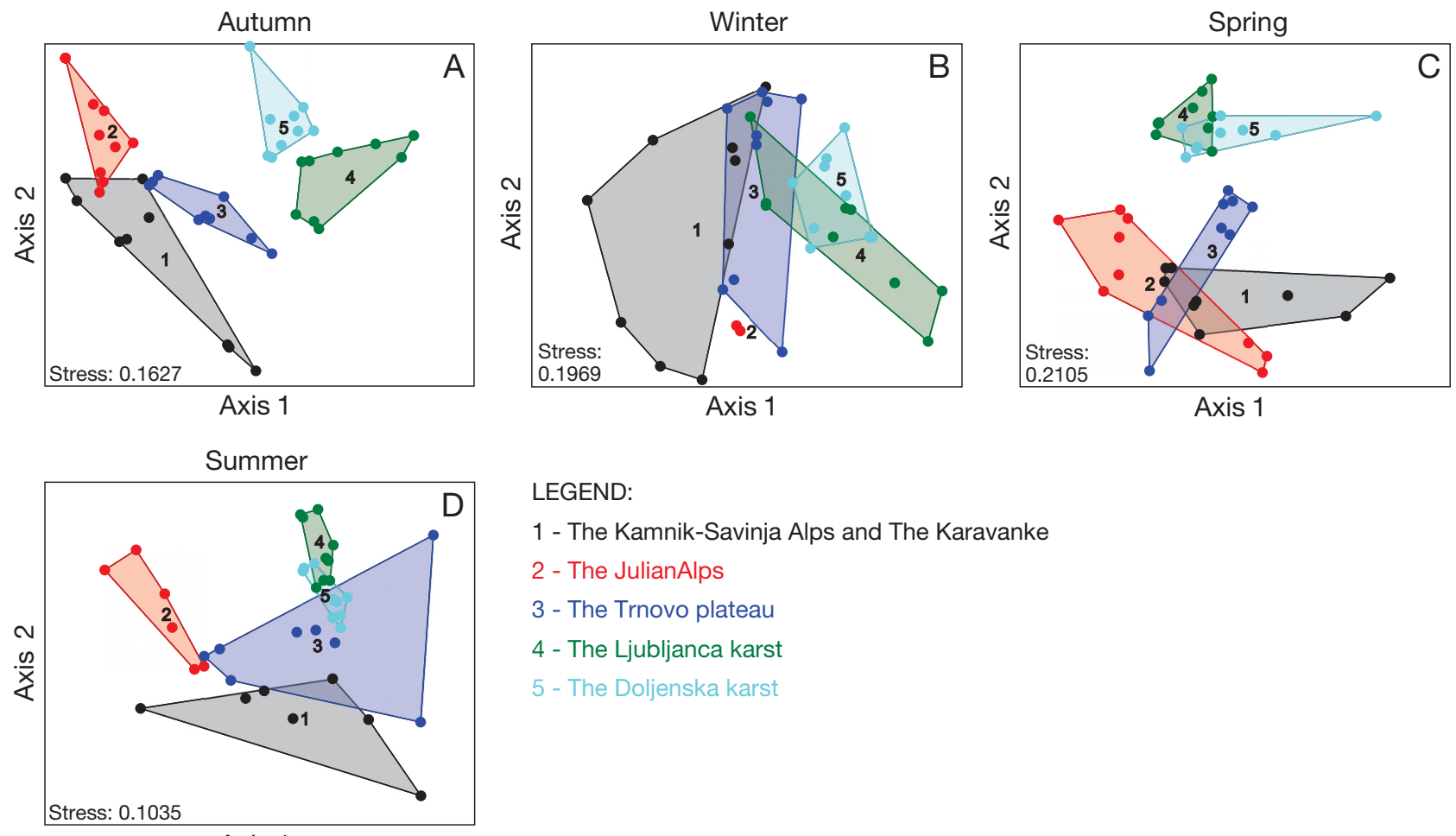

LEGEND:

1 - The Kamnik-Savinja Alps and The Karavanke

2 - The JulianAlps

3 - The Trnovo plateau

4 - The Ljubljanca karst

5 - The Doljenska karst

Fig. 4. Non-metric multi-dimensional scaling analyses based on Bray-Curtis similarities of bacterial community structure of 15 springs from 5 karst eco-regions in Slovenia (the Kamnik-Savinja-Karavanke Alps, the Julian Alps, the Trnovo plateau, the Ljubljanica karst, and the Dolenjska karst) sampled across 4 seasons in the sampling period from October 2014 to August 2015. Each enclosed shape with 9 points represents 3 springs in triplicate (as some samples did not have enough DNA for analyses, there are fewer points in some frames)

atively correlated with $\mathrm{pH}$ (detailed results in Table 5).

We tested our third hypothesis, i.e. a decrease in microbial abundance and activity with increasing altitude of the catchment, using hierarchical multiple regression analysis. Both TCC and ETSA decreased significantly with increasing catchment altitude (on a $\log$-log scale; Fig. 7), explaining 43.5 and $28.4 \%$ of the variation in TCC and ETSA, respectively (i.e. adjusted $\mathrm{R}^{2}$; detailed results in Table 6). No additional significant effect of season was observed when including season as additional categorical co-variable in the models.

\section{DISCUSSION}

To date, most of the studies on groundwater microbial communities have addressed contaminated aquifers, with only a few that looked at pristine groundwater ecosystems, and even fewer into karst aquifers (Farnleitner et al. 2005, Goldscheider et al. 2006, Pronk et al. 2009, Zhou et al. 2012, Shabarova et al. 2013, 2014, Wilhartitz et al. 2013, Sinreich et al.
2014). The aim of this study was to provide an improved understanding of the effect of individual environmental conditions and seasonal variation on prokaryotic abundance, microbial activity, and bacterial community structure in karst aquifers. We studied the spatio-temporal dynamics of microbial communities in waters from 15 springs situated in 5 geographically distinct karst eco-regions in Slovenia, spanning about $50 \mathrm{~km}$ in north-south direction and $1200 \mathrm{~m}$ in altitude.

Previous studies have reported an influence of environmental conditions on groundwater microbial community biomass, activity, and composition (Stegen et al. 2013, Sirisena et al. 2014, Beyer et al. 2015, Graham et al. 2016, 2017, Fillinger et al. 2019, Yan et al. 2020), and as the environmental characteristics of the catchments differed between the 5 studied ecoregions, we hypothesized that the bacterial communities within eco-regions would be more similar to each other than between eco-regions. With nMDS and ANOSIM analyses, this hypothesis was confirmed; our results were in line with the findings by Danczak et al. (2018) and Fillinger et al. (2019), who reported significant variations for microbial commu- 


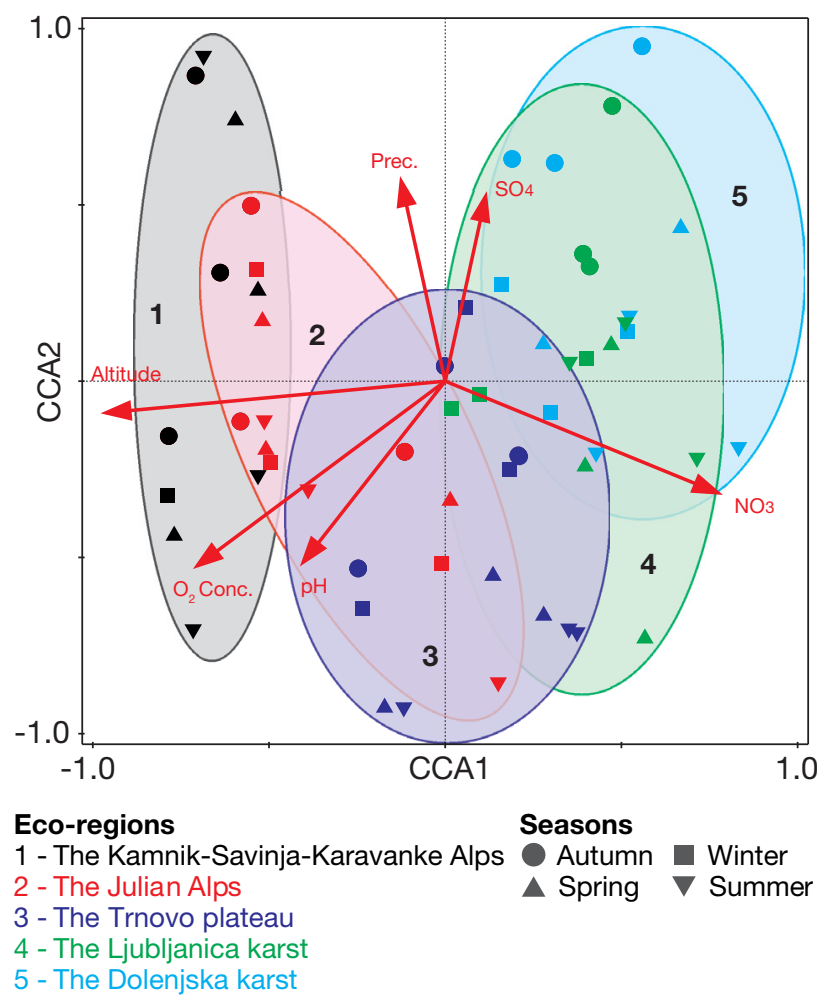

Fig. 5. Canonical correspondence analysis (CCA) ordination biplot of bacterial community structure across 5 karst ecoregions. Arrows indicate the magnitude and direction of the most significant environmental variables associated with bacterial community structure. Altitude: altitude of catchment; $\mathrm{O}_{2}$ Conc.: oxygen concentration; Prec.: precipitation within $7 \mathrm{~d}$ before sampling

nities of different aquifers. We identified catchment altitude, which showed an inverse relationship with $\mathrm{NO}_{3}{ }^{-}$concentrations in the spring water, as well as the amount of precipitation, $\mathrm{pH}$, and concentrations of DO and sulphate as the main environmental factors determining bacterial community structure across the 5 eco-regions. The importance of environmental conditions in shaping subsurface microbial communities has been previously underlined (Ben
Maamar et al. 2015, Graham et al. 2016, 2017, Fillinger et al. 2019, Zelaya et al. 2019, Yan et al. 2020); water $\mathrm{pH}$ especially has been reported as a key factor, outweighing even the contribution of high temperatures to the biogeographic distribution of microbial communities in geothermal springs across an area of $\sim 8000 \mathrm{~km}^{2}$ (Power et al. 2018). Results of our study are further comparable to boreal aquatic ecosystems (Niño-García et al. 2016), where a clear separation into regional groups was obtained based on differences in the water chemistry of surface lakes and rivers; however, in terms of bacterial community structures, smaller regional differences were shown, with a significant overlap between sites from different regions. They showed that $\mathrm{pH}$ and water residence time were the most important environmental variables shaping bacterial community structure in the selected research area (Niño-García et al. 2016). In our study, environmental conditions only explained a small fraction of the variation in microbial community structure $(\sim 15 \%)$, which might point towards a strong influence of other factors, such as stochastic dispersal of taxa via groundwater discharge as has previously been observed for other karst systems (Shabarova et al. 2013, 2014, Savio et al. 2019). Unfortunately, during this study it was not possible to test bacterial community data with the groundwater residence time and hydrological regime.

It is important to note that the present observations on microbial community structure based on T-RFLP fingerprints might not be directly comparable with those other studies, which assessed microbial community composition at a higher resolution using high-throughput amplicon sequencing. The T-RFLP fingerprinting was implemented here only to detect the most abundant fraction of taxa in the communities while missing rare, low-abundant taxa that often actually comprise the bulk of the total taxon richness in microbial communities (Jia et al. 2018). Although it is still unresolved whether the assembly of rare

Table 3. Prokaryotic abundance (total cell counts; cells $\mathrm{ml}^{-1}$ ) of 5 karst eco-regions (mean \pm SD of 3 springs per eco-region) for 4 seasons during the sampling period from October 2014 to August 2015. Regional and seasonal averages are included

\begin{tabular}{|c|c|c|c|c|c|}
\hline Eco-region & Autumn & Winter & Spring & Summer & Regional average \\
\hline $\begin{array}{l}\text { 1. The Kamnik-Savinja- } \\
\text { Karavanke Alps }\end{array}$ & $4.1 \times 10^{4} \pm 4.8 \times 10^{4}$ & $1.1 \times 10^{4} \pm 1.6 \times 10^{3}$ & $1.9 \times 10^{4} \pm 1.2 \times 10^{4}$ & $2.0 \times 10^{4} \pm 4.4 \times 10^{3}$ & $2.3 \times 10^{4} \pm 2.4 \times 10^{4}$ \\
\hline 2. The Julian Alps & $1.6 \times 10^{4} \pm 8.7 \times 10^{3}$ & $1.8 \times 10^{4} \pm 7.2 \times 10^{3}$ & $1.2 \times 10^{5} \pm 1.1 \times 10^{5}$ & $1.0 \times 10^{5} \pm 1.1 \times 10^{5}$ & $6.4 \times 10^{4} \pm 8.2 \times 10^{4}$ \\
\hline 3. The Trnovo plateau & $8.0 \times 10^{4} \pm 4.9 \times 10^{4}$ & $2.7 \times 10^{4} \pm 1.5 \times 10^{4}$ & $6.6 \times 10^{4} \pm 4.8 \times 10^{4}$ & $5.3 \times 10^{4} \pm 2.1 \times 10^{4}$ & $5.6 \times 10^{4} \pm 3.7 \times 10^{4}$ \\
\hline 4. The Ljubljanica karst & $9.5 \times 10^{4} \pm 4.0 \times 10^{4}$ & $5.5 \times 10^{4} \pm 1.8 \times 10^{4}$ & $1.0 \times 10^{5} \pm 2.9 \times 10^{4}$ & $1.6 \times 10^{5} 1 \pm 6.6 \times 10^{4}$ & $1.0 \times 10^{5} \pm 5.2 \times 10^{4}$ \\
\hline 5. The Dolenjska karst & $3.9 \times 10^{5} \pm 3.4 \times 10^{4}$ & $4.8 \times 10^{4} \pm 1.7 \times 10^{4}$ & $8.1 \times 10^{4} \pm 1.9 \times 10^{4}$ & $1.2 \times 10^{4} \pm 2.4 \times 10^{4}$ & $1.6 \times 10^{5} \pm 1.4 \times 10^{5}$ \\
\hline Seasonal average & $1.2 \times 10^{5} \pm 1.4 \times 10^{5}$ & $3.2 \times 10^{4} \pm 2.1 \times 10^{4}$ & $7.7 \times 10^{4} \pm 5.9 \times 10^{4}$ & $9.0 \times 10^{4} \pm 7.0 \times 10^{4}$ & $8.1 \times 10^{4} \pm 9.0 \times 10^{4}$ \\
\hline
\end{tabular}




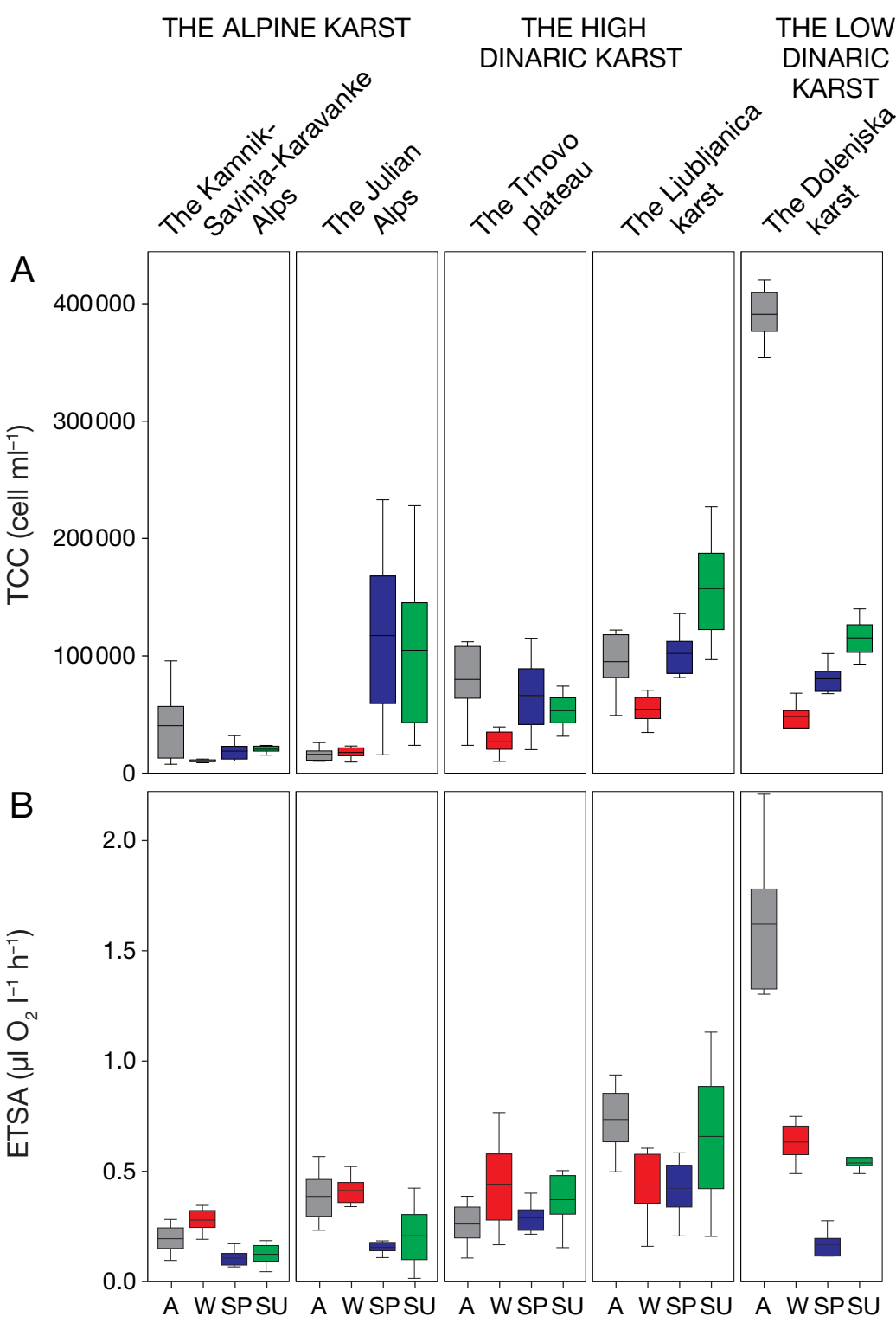

Fig. 6. Total cell counts (TCCs) and electron transport system activity (ETSA) for 15 springs from 5 karst eco-regions in Slovenia (Central Europe) across the 4 sampling seasons from October 2014 to August 2015. Middle horizontal lines: mean values; boxes: lower and upper quartiles; whiskers: minimum and maximum values; A: autumn; W: winter; SP: spring; SU: summer and abundant taxa underlies similar mechanisms (Liao et al. 2017, Jia et al. 2018, Mo et al. 2018, Nyirabuhoro et al. 2020), we have to take into account that the factors that were identified to influence microbial community structure based on T-RFLP in our study likely only reflect the impact on the most abundant taxa and thus might not be representative of the microbial communities as a whole. Considering this potential bias, our conclusions based on the effects of environmental conditions and regional features of the catchments need to be treated with the necessary caution.

We confirmed the hypothesis that the bacterial communities were more similar within than between seasons; but in association with the second hypothesis, we further confirmed that differences in eco-regional patterns have a stronger impact on bacterial community structure than seasonality. While the temporal variability in groundwater chemical composition has historically been regarded to be comparably low (Nelson 2002), seasonal dynamics of groundwater chemistry and microbiology strongly depend on the type of aquifer (e.g. alluvial versus karst; Griebler et al. 2010) as well as its geographical location and altitude (Farnleitner et al. 2005). The largest seasonal variations in groundwater chemistry have been observed and are expected in karst systems due to high variability in the quantity of discharge and flow velocities, which depend on the position,

Table 4. Electron transport system activity $\left(\mathrm{ETSA}_{;} \mu \mathrm{O}_{2} \mathrm{l}^{-1} \mathrm{~h}^{-1}\right)$ values of 5 karst eco-regions (mean \pm SD of 3 springs per ecoregion) for 4 seasons during the sampling period from October 2014 to August 2015. Regional and seasonal averages are included

\begin{tabular}{|lccccc|}
\hline Eco-region & Autumn & Winter & Spring & Summer & Regional average \\
\hline 1. The Kamnik-Savinja- & $0.194 \pm 0.093$ & $0.279 \pm 0.079$ & $0.107 \pm 0.057$ & $0.124 \pm 0.072$ & $0.185 \pm 0.096$ \\
$\quad$ Karavanke Alps & & & & & \\
2. The Julian Alps & $0.386 \pm 0.169$ & $0.413 \pm 0.096$ & $0.155 \pm 0.041$ & $0.208 \pm 0.206$ & $0.294 \pm 0.168$ \\
3. The Trnovo plateau & $0.261 \pm 0.142$ & $0.441 \pm 0.303$ & $0.289 \pm 0.099$ & $0.372 \pm 0.190$ & $0.345 \pm 0.185$ \\
4. The Ljubljanica karst & $0.735 \pm 0.222$ & $0.438 \pm 0.243$ & $0.420 \pm 0.193$ & $0.658 \pm 0.463$ & $0.566 \pm 0.293$ \\
5. The Dolenjska karst & $1.621 \pm 0.511$ & $0.633 \pm 0.132$ & $0.169 \pm 0.092$ & $0.538 \pm 0.042$ & $0.735 \pm 0.606$ \\
Seasonal average & $0.639 \pm 0.590$ & $0.441 \pm 0.200$ & $0.228 \pm 0.150$ & $0.380 \pm 0.292$ & $0.422 \pm 0.374$ \\
\hline
\end{tabular}


Table 5. Spearman's rank-order correlation analysis of total cell counts (TCC), electron transport system activity (ETSA), dissolved organic carbon (DOC), and $\mathrm{pH}$ correlated with catchment area characteristics. $T_{\text {water }}$ : water temperature; EC: electrical conductivity; $T_{\text {air }}$ air temperature; ${ }^{*} \mathrm{p}<0.05_{;}{ }^{* *} \mathrm{p}<0.01$ (2-tailed). The strongest correlations are in bold

\begin{tabular}{|c|c|c|c|c|c|}
\hline Variable & Spearman's rho & TCC & ETSA & DOC & $\mathrm{pH}$ \\
\hline \multirow[t]{3}{*}{ TCC } & $r_{s}$ & 1.000 & $0.521^{* *}$ & $0.495^{* *}$ & -0.251 \\
\hline & Sig. (2-tailed) & & 0.000 & 0.000 & 0.053 \\
\hline & $\mathrm{N}$ & 60 & 60 & 57 & 60 \\
\hline \multirow[t]{3}{*}{ ETSA } & $\mathrm{r}_{\mathrm{s}}$ & $0.521^{* *}$ & 1.000 & 0.181 & $-0.398^{* *}$ \\
\hline & Sig. (2-tailed) & 0.000 & & 0.177 & 0.002 \\
\hline & $\mathrm{N}$ & 60 & 60 & 57 & 60 \\
\hline \multirow[t]{3}{*}{ DOC } & $r_{s}$ & $0.495^{* *}$ & 0.181 & 1.000 & 0.034 \\
\hline & Sig. (2-tailed) & 0.000 & 0.177 & & 0.803 \\
\hline & $\mathrm{N}$ & 57 & 57 & 57 & 57 \\
\hline \multirow[t]{3}{*}{$\mathrm{pH}$} & $r_{s}$ & -0.251 & $-0.398^{* *}$ & 0.034 & 1.000 \\
\hline & Sig. (2-tailed) & 0.053 & 0.002 & 0.803 & \\
\hline & $\mathrm{N}$ & 60 & 60 & 57 & 60 \\
\hline \multirow[t]{3}{*}{$T_{\text {water }}$} & $\mathrm{r}_{\mathrm{s}}$ & $0.606^{* *}$ & $0.514^{* *}$ & $0.418^{* *}$ & $-0.443^{* *}$ \\
\hline & Sig. (2-tailed) & 0.000 & 0.000 & 0.001 & 0.000 \\
\hline & $\mathrm{N}$ & 60 & 60 & 57 & 60 \\
\hline \multirow[t]{3}{*}{$\mathrm{O}_{2}$ concentration } & $r_{s}$ & $-0.483^{* *}$ & $-0.393^{* *}$ & $-0.315^{*}$ & $0.339^{* *}$ \\
\hline & Sig. (2-tailed) & 0.000 & 0.002 & 0.017 & 0.008 \\
\hline & $\mathrm{N}$ & 60 & 60 & 57 & 60 \\
\hline \multirow[t]{3}{*}{ EC } & $r_{s}$ & $0.610^{* *}$ & $0.655^{* *}$ & $0.315^{*}$ & $-0.639^{* *}$ \\
\hline & Sig. (2-tailed) & 0.000 & 0.000 & 0.017 & 0.000 \\
\hline & $\mathrm{N}$ & 60 & 60 & 57 & 60 \\
\hline \multirow[t]{3}{*}{$\mathrm{Cl}^{-}$} & $\mathrm{r}_{\mathrm{s}}$ & $0.401^{* *}$ & $0.417^{* *}$ & 0.159 & $-0.398^{* *}$ \\
\hline & Sig. (2-tailed) & 0.002 & 0.001 & 0.238 & 0.002 \\
\hline & $\mathrm{N}$ & 60 & 60 & 57 & 60 \\
\hline \multirow[t]{3}{*}{$\mathrm{NO}_{3}{ }^{-}$} & $r_{s}$ & $0.499^{* *}$ & $0.385^{* *}$ & $0.287^{*}$ & $-0.276^{*}$ \\
\hline & Sig. (2-tailed) & 0.000 & 0.002 & 0.031 & 0.033 \\
\hline & $\mathrm{N}$ & 60 & 60 & 57 & 60 \\
\hline \multirow[t]{3}{*}{$\mathrm{SO}_{4}{ }^{2-}$} & $\mathrm{r}_{\mathrm{s}}$ & 0.132 & $0.298^{*}$ & 0.027 & $-0.304^{*}$ \\
\hline & Sig. (2-tailed) & 0.314 & 0.021 & 0.845 & 0.018 \\
\hline & $\mathrm{N}$ & 60 & 60 & 57 & 60 \\
\hline \multirow[t]{3}{*}{$\mathrm{Na}^{+}$} & $r_{s}$ & $0.433^{* *}$ & $0.486^{* *}$ & 0.168 & $-0.438^{* *}$ \\
\hline & Sig. (2-tailed) & 0.001 & 0.000 & 0.211 & 0.000 \\
\hline & $\mathrm{N}$ & 60 & 60 & 57 & 60 \\
\hline \multirow[t]{3}{*}{$\mathrm{NH}_{4}^{+}$} & $r_{s}$ & $0.349^{*}$ & 0.325 & 0.102 & -0.324 \\
\hline & Sig. (2-tailed) & 0.043 & 0.061 & 0.587 & 0.061 \\
\hline & $\mathrm{N}$ & 34 & 34 & 31 & 34 \\
\hline \multirow[t]{3}{*}{$\mathrm{K}^{+}$} & $\mathrm{r}_{\mathrm{s}}$ & $0.542^{* *}$ & $0.560^{* *}$ & 0.135 & $-0.442^{* *}$ \\
\hline & Sig. (2-tailed) & 0.000 & 0.000 & 0.323 & 0.000 \\
\hline & $\mathrm{N}$ & 59 & 59 & 56 & 59 \\
\hline \multirow[t]{3}{*}{$\mathrm{Ca}^{2+}$} & $\mathrm{r}_{\mathrm{s}}$ & $0.605^{* *}$ & $0.623^{* *}$ & $0.367^{* *}$ & $-0.612^{* *}$ \\
\hline & Sig. (2-tailed) & 0.000 & 0.000 & 0.005 & 0.000 \\
\hline & $\mathrm{N}$ & 60 & 60 & 57 & 60 \\
\hline $\mathrm{Mg}^{2+}$ & $\mathrm{r}_{\mathrm{s}}$ & 0.114 & 0.174 & -0.032 & -0.216 \\
\hline & Sig. (2-tailed) & 0.388 & 0.183 & 0.813 & 0.097 \\
\hline & $\mathrm{N}$ & 60 & 60 & 57 & 60 \\
\hline Precipitation within & $\mathrm{r}_{\mathrm{s}}$ & $0.264^{*}$ & -0.040 & 0.006 & -0.063 \\
\hline $7 \mathrm{~d}$ before sampling & Sig. (2-tailed) & 0.042 & 0.761 & 0.966 & 0.631 \\
\hline & $\mathrm{N}$ & 60 & 60 & 57 & 60 \\
\hline Altitude of catchment & $\mathrm{r}_{\mathrm{s}}$ & $-0.615^{* *}$ & $-0.567^{* *}$ & $-0.299^{*}$ & -0.249 \\
\hline & Sig. (2-tailed) & 0.000 & 0.000 & 0.024 & 0.436 \\
\hline & $\mathrm{N}$ & 60 & 60 & 57 & 12 \\
\hline Altitude of spring & $\mathrm{r}_{\mathrm{s}}$ & $-0.550^{* *}$ & $-0.447^{* *}$ & $-0.425^{* *}$ & $0.495^{* *}$ \\
\hline & Sig. (2-tailed) & 0.000 & 0.000 & 0.001 & 0.000 \\
\hline & $\mathrm{N}$ & 60 & 60 & 57 & 60 \\
\hline Catchment area & $\mathrm{r}_{\mathrm{s}}$ & $0.546^{* *}$ & $0.427^{* *}$ & $0.292^{*}$ & $0.397^{* *}$ \\
\hline & Sig. (2-tailed) & 0.000 & 0.001 & 0.027 & 0.002 \\
\hline & $\mathrm{N}$ & 60 & 60 & 57 & 60 \\
\hline Mean amount of & $\mathrm{r}_{\mathrm{s}}$ & $-0.463^{* *}$ & $-0.424^{* *}$ & -0.145 & $-0.418^{* *}$ \\
\hline precipitation & Sig. (2-tailed) & 0.000 & 0.001 & 0.281 & 0.001 \\
\hline & $\mathrm{N}$ & 60 & 60 & 57 & 60 \\
\hline Mean annual $T_{\text {air }}$ & $\mathrm{r}_{\mathrm{s}}$ & $0.590^{* *}$ & $0.532^{* *}$ & 0.252 & $0.395^{* *}$ \\
\hline & Sig. (2-tailed) & 0.000 & 0.000 & 0.059 & 0.002 \\
\hline & $\mathrm{N}$ & 60 & 60 & 57 & 60 \\
\hline
\end{tabular}

structure, and size of voids and fissures in the karst rock massive (Pronk et al. 2009, Zhou et al. 2012). However, our study provides evidence that the differences between eco-regions in Slovenia, with respect to groundwater composition, exceed the seasonal oscillations; exceptions were $\mathrm{DOC}$ and $\mathrm{pH}$. DOC in groundwater mainly derives from terrestrial ecosystems, i.e. direct leaching after leaf fall and from decomposing $\mathrm{OM}$ in the soil layer (Gooddy \& Hinsby 2008), which depends on the season that determines surface temperature, hydrological conditions, and litterfall decomposition (Kirschbaum 2006). In our study area, air temperature peaks in summer, hydrological discharge and flow peak in spring and autumn (from heavy rain events and snow melting), while litterfall, leaching, and decomposition peak in autumn. Consequently, significant seasonal variations of DOC in groundwater occurred $\left(\mathrm{DOC}_{\max }\right.$ in autumn, $\mathrm{DOC}_{\text {min }}$ in winter). Besides seasons, DOC is significantly correlated with the altitude of the spring, water temperature, EC, and calcium and oxygen concentrations. The median concentration of DOC in the investigated spring waters $\left(2.4 \mathrm{mg} \mathrm{l}^{-1}\right)$ is comparable to DOC concentrations from other European groundwaters, with median concentrations of about $2 \mathrm{mg} \mathrm{l}^{-1}$ (Gooddy \& Hinsby 2008). The variations in $\mathrm{pH}$ values can be explained by local environmental temperature, mineral composition of the geological strata, hydrological dynamics, and soil composition (Nelson 2002). Thus in our study, EC and calcium concentration showed significant correlation with $\mathrm{pH}$, as well as the altitude of the spring, water temperature, sodium and potassium concentrations, and mean annual amount of precipitation. Accordingly, water $\mathrm{pH}$ was highest in summer and lowest in autumn. The median groundwater $\mathrm{pH}$ value from our study sites in Slovenia $(8.0 \pm 0.3)$ was slightly higher than other European limestone groundwaters (7.2-7.8) 


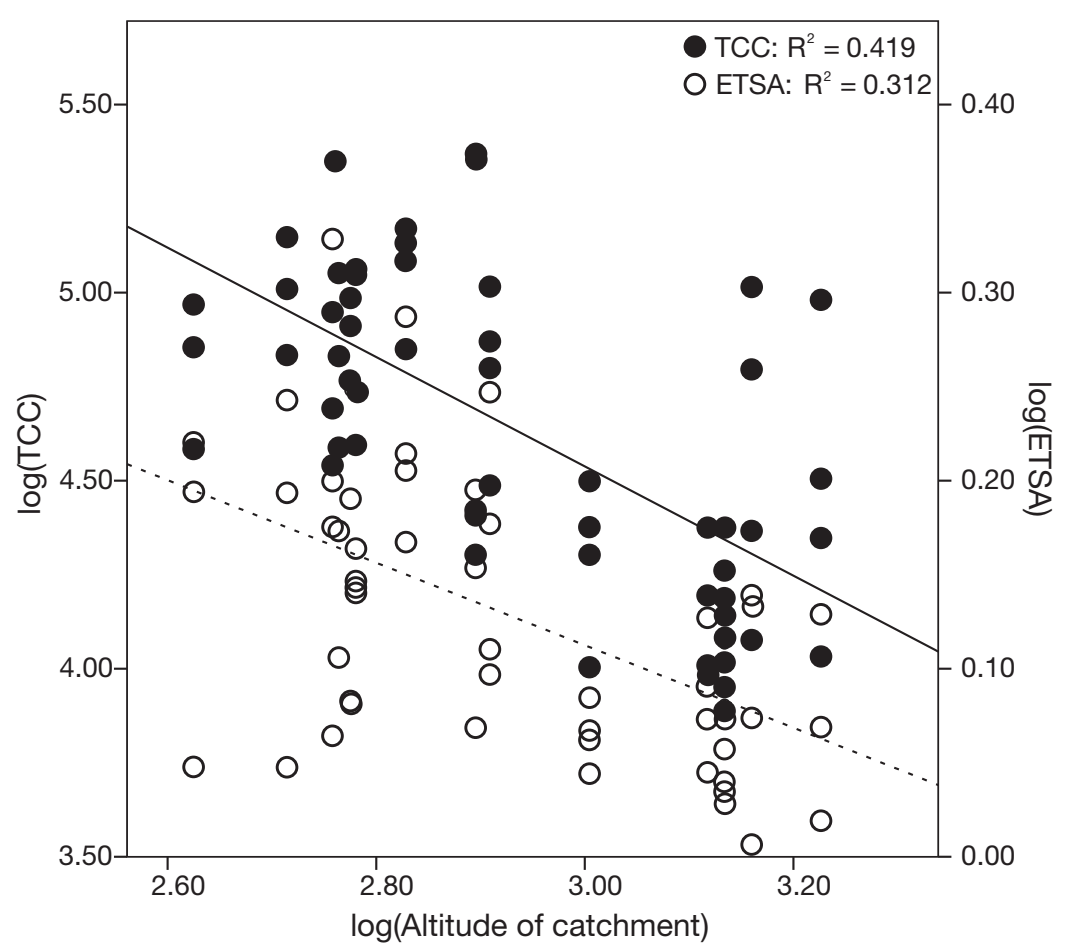

Fig. 7. Log of total cell count (TCC; solid black line) and log of electron transport system activity (ETSA; dashed black line) versus log altitude of catchment

(2018), who also highlighted the crucial role of the composition and quality of OM. In our study, TCC was significantly correlated with EC, water temperature, calcium concentration, mean annual air temperature, as well as with the altitude of spring and size of the catchment area. The results of TCC from Slovenian karst aquifers showed strong seasonal variation in comparison to other pristine alluvial aquifers (Stein et al. 2010, Zhou et al. 2012), which was expected due to the more dynamic karst systems (Shabarova et al. 2013, 2014, Savio et al. 2019). The ETSA values of spring water in our study were on average lower than the ETSA of the surface and interstitial waters of a prealpine river in Slovenia (Simčič \& Mori 2007), which was predicted due to lower microbial biomass in the groundwater (Griebler \& Lueders 2009). In our study, significant correlations with catchment area characteristics were found, especially

(Wendland et al. 2008). Seasonality was also reflected in the dynamics of abundances of prokaryotic cells (i.e. TCC) and microbial respiratory activities (i.e. ETSA) in spring water, which again showed a relationship with DOC dynamics (e.g. the highest values in autumn, the lowest in winter). The correlation between DOC and prokaryotic abundance was previously mentioned by Hofmann \& Griebler strong with EC, concentration of calcium and potassium ions, and mean annual air temperature and water temperature; however, in interstitial waters, researchers found no significant correlation between ETSA and basic physico-chemical variables (Simčič \& Mori 2007), which could be a result of shorter sampling period and smaller sampling area.

Table 6. Summary of hierarchical multiple regression results for 2 models (without and with season) including significant variable, total and adjusted $\mathrm{R}^{2}$ (variance explained), $F$ and regression slope $(\beta)$ with p-values explaining $\log (\mathrm{TCC})(\mathrm{n}=60)$ and $\log (\mathrm{ETSA})(\mathrm{n}=57)$. TCC: total prokaryotic cell counts; ETSA: electron transport system activity

\begin{tabular}{|c|c|c|c|c|c|c|}
\hline Result explained & Model & Significant variable & Total $\mathrm{R}^{2}$ & $\begin{array}{c}\text { Adjusted } R^{2} \\
(\%)\end{array}$ & $F$ and $\mathrm{p}$ & $\beta$ and $p$ \\
\hline \multirow[t]{2}{*}{$\log (\mathrm{TCC})$} & 1 & Log(altitude of catchment) & 0.457 & 43.5 & $\begin{array}{l}F_{1,25}=21.029 \\
\mathrm{p}<0.001\end{array}$ & $\begin{array}{l}\beta=-0.676 \\
p<0.001\end{array}$ \\
\hline & 2 & $\begin{array}{l}\text { Log(altitude of catchment) } \\
\text { Season }\end{array}$ & 0.469 & 42.5 & $\begin{array}{l}F_{2,24}=10.614 \\
\mathrm{p}<0.001\end{array}$ & $\begin{array}{l}\beta=-0.676 \\
p<0.001 \\
\beta=0.112 \\
p=0.459\end{array}$ \\
\hline \multirow[t]{2}{*}{$\log ($ ETSA $)$} & 1 & Log(altitude of catchment) & 0.312 & 28.4 & $\begin{array}{l}F_{1,25}=11.317 \\
\mathrm{p}=0.002\end{array}$ & $\begin{array}{l}\beta=-0.558 \\
p=0.002\end{array}$ \\
\hline & 2 & $\begin{array}{l}\text { Log(altitude of catchment) } \\
\text { Season }\end{array}$ & 0.330 & 27.4 & $\begin{array}{l}F_{2,24}=5.912 \\
\mathrm{p}=0.008\end{array}$ & $\begin{array}{l}\beta=-0.558 \\
p=0.003 \\
\beta=-0.136 \\
p=0.424\end{array}$ \\
\hline
\end{tabular}


Significant regional differences were also shown for prokaryotic abundance and microbial respiratory activities. A negative correlation was found between prokaryotic abundance and microbial activity with catchment altitude (Hypothesis 3). A similar altitudinal pattern was observed for the richness and diversity in stream bacteria (epilithic biofilms) (Wilhelm et al. 2015), which could be due to an increase in DOC diversity downstream. Similar results were shown for soil bacteria (Bryant et al. 2008); the authors of that study suggested a combined influence of soil temperature, $\mathrm{pH}$, and total nitrogen as the most important predictors of bacterial community composition. However, Wang et al. (2011) showed contrasting results of bacterial biofilms in the streams, where a monotone increasing pattern with altitude was demonstrated, and Fierer et al. (2011) showed no significant altitudinal pattern in soil bacteria at all. The eco-regions addressed in our study showed an increasing surface area covered by meadows and forests with lower catchment altitude, which resulted in an increase in thickness of soil cover and seasonal leaf mass as well as increasing DOC concentration down-gradient. At the same time, areas at lower altitudes harbour larger human population densities than higher alpine regions. This may explain higher $\mathrm{NO}_{3}{ }^{-}$concentrations, released from diffusive (agricultural land) and point sources (waste water discharge), which in turn could have contributed to an elevation of microbial abundance and activity in the aquifers at lower altitudes. We propose that future studies should address microbial community composition at a higher resolution while also considering further important key variables describing the hydrological cycle, such as water age and residence time. Moreover, focus should be on the energetic basis of the microbes and their functions, addressing the metagenome and transcriptome, as well as the biodegradability of the DOM.

Acknowledgements. The authors acknowledge the financial support from the Slovenian Research Agency: ARRS; research programmes P1-0255 and P4-0116 with a programme for young researchers in accordance with the agreement on (co)financing the research activity in 2018: No. 1000-18-0105. We are grateful to our colleagues Allen Wei Liu, Barbara Debeljak and Tina Jaklič for their help during field work, as well as Andreja Jerebic, Tatjana Simčič, and Marilyne Pflieger for their help with individual laboratory analyses. We are grateful to Jennifer Claire Ellis for linguistic corrections.

\section{LITERATURE CITED}

ARSO (Agencija Republike Slovenije za Okolje) (2014a) Arhiv - Letni podatki. Slovenian Environment Agency. http://meteo.arso.gov.si/met/sl/archive/ (accessed 15 Sep 2014)

ARSO (2014b) Hidrološki arhiv — Vode - Mesečne statistike. Slovenian Environment Agency. www.arso.gov.si/vode/ podatki/arhiv/hidroloski_arhiv.html (accessed 15 Sep 2014)

* Bayer A, Drexel R, Weber N, Griebler C (2016) Quantification of aquatic sediment prokaryotes - a multiple-steps optimization testing sands from pristine and contaminated aquifers. Limnologica 56:6-13

* Ben Maamar S, Aquilina L, Quaiser A, Pauwels H and others (2015) Groundwater isolation governs chemistry and microbial community structure along hydrologic flowpaths. Front Microbiol 6:1457

Beyer A, Rzanny M, Weist A, Möller S and others (2015) Aquifer community structure in dependence of lithostratigraphy in groundwater reservoirs. Environ Sci Pollut Res Int 22:19342-19351

Botosaneanu L (ed) (1986) Stygofauna mundi: a faunistic, distributional, and ecological synthesis of the world fauna inhabiting subterranean waters (including the marine interstitial). EJ Brill, Leiden

Brečko Grubar V, Plut D (2001) Kakovost virov pitne vode v Sloveniji. Ujma 14-15:238-244

Bryant JA, Lamanna C, Morlon H, Kerkhoff AJ and others (2008) Microbes on mountainsides: contrasting elevational patterns of bacterial and plant diversity. Proc Natl Acad Sci USA 105:11505-11511

Cerar S (2016) A spatial model of groundwater chemical composition in Slovenia in GIS environment. PhD dissertation, University of Ljubljana

Comte J, Berga M, Severin I, Logue JB, Lindström ES (2017) Contribution of different bacterial dispersal sources to lakes: population and community effects in different seasons. Environ Microbiol 19:2391-2404

* Danczak RE, Johnston MD, Kenah C, Slattery M, Wilkins MJ (2018) Microbial community cohesion mediates community turnover in unperturbed aquifers. mSystems 3: e00066-e18

*Danielopol DL, Pospisil P, Rouch R (2000) Biodiversity in groundwater: a large-scale view. Trends Ecol Evol 15: 223-224

Farnleitner AH, Wilhartitz I, Ryzinska G, Kirschner AKT and others (2005) Bacterial dynamics in spring water of alpine karst aquifers indicates the presence of stable autochthonous microbial endokarst communities. Environ Microbiol 7:1248-1259

*Feichtmayer J, Deng L, Griebler C (2017) Antagonistic microbial interactions: contributions and potential applications for controlling pathogens in the aquatic systems. Front Microbiol 8:2192

Fierer N, McCain CM, Meir P, Zimmermann M and others (2011) Microbes do not follow the elevational diversity patterns of plants and animals. Ecology 92:797-804

Fillinger L, Hug K, Griebler C (2019) Selection imposed by local environmental conditions drives differences in microbial community composition across geographically distinct groundwater aquifers. FEMS Microbiol Ecol 95: fiz160

G.-Tóth L (1999) Aktivität des Electronentransportsystems. In: von Tumpling W, Friedrich G (eds) Biologische Gewässeruntersuchung. Methoden der Biologische Wasseruntersuchung, Vol 2. Gustav Fischer Verlag, Stuttgart, p 465-473

Gams I (1974) Kras: zgodovinski, naravoslovni in geografski oris. Slovenska matica, Ljubljana 
Gibert J, Culver DC (2009) Assessing and conserving groundwater biodiversity: an introduction. Freshw Biol 54:639-648

Goldscheider N, Hunkeler D, Rossi P (2006) Review: microbial biocenoses in pristine aquifers and an assessment of investigative methods. Hydrogeol J 14:926-941

Gooddy DC, Hinsby K (2008) Organic quality of groundwaters. In: Edmunds WM, Shand P (eds) Natural groundwater quality. Blackwell Publishing, Oxford, p 59-70

Graham EB, Crump AR, Resch CT, Fansler S and others (2016) Coupling spatiotemporal community assembly processes to changes in microbial metabolism. Front Microbiol 7:1949

* Graham EB, Crump AR, Resch CT, Fansler S and others (2017) Deterministic influences exceed dispersal effects on hydrologically-connected microbiomes. Environ Microbiol 19:1552-1567

Griebler C, Avramov M (2015) Groundwater ecosystem services: a review. Freshw Sci 34:355-367

* Griebler C, Lueders T (2009) Microbial biodiversity in groundwater ecosystems. Freshw Biol 54:649-677

Griebler C, Stein H, Kellermann C, Berkhoff S and others (2010) Ecological assessment of groundwater ecosystems - Vision or illusion? Ecol Eng 36:1174-1190

Griebler C, Avramov M, Hose G (2019) Groundwater ecosystems and their services: current status and potential risks. In: Schröter M, Bonn A, Klotz S, Seppelt R, Baessler C (eds) Atlas of ecosystem services. Springer, Berlin, p 197-203

Hammer Ø, Harper DAT, Ryan PD (2001) PAST: paleontological statistics software package for education and data analysis. Palaeontol Electronica 4:9

Hammes F, Berney M, Wang Y, Vital M and others (2008) Flow-cytometric total bacterial cell counts as a descriptive microbiological parameter for drinking water treatment processes. Water Res 42:269-277

Heuer H, Smalla K (1997) Application of denaturing gradient gel electrophoresis and temperature gradient gel electrophoresis for studying soil microbial communities. In: van Elsas JD, Trevors JT, Wellington EMH (eds) Modern soil microbiology. Marcel Dekker, New York, NY, p 353-373

Hofmann R, Griebler C (2018) DOM and bacterial growth efficiency in oligotrophic groundwater: absence of priming and co-limitation by organic carbon and phosphorus. Aquat Microb Ecol 81:55-71

IBM Corporation (2011) IBM SPSS Statistics for Windows, version 20.0. IBM Corporation, Armonk, NY

Jia X, Dini-Andreote F, Salles JF (2018) Community assembly processes of the microbial rare biosphere. Trends Microbiol 26:738-747

Kenner R, Ahmed S (1975) Measurements of electron transport activities in marine phytoplankton. Mar Biol 33: 119-127

Kirschbaum MUF (2006) The temperature dependence of organic-matter decomposition-still a topic of debate. Soil Biol Biochem 38:2510-2518

Korbel K, Hose G (2011) A tiered framework for assessing groundwater ecosystem health. Hydrobiologia 661: 329-349

Langenheder S, Lindström ES (2019) Factors influencing aquatic and terrestrial bacterial community assembly. Environ Microbiol Rep 11:306-315

KLiao J, Cao X, Wang J, Zhao L and others (2017) Similar community assembly mechanisms underlie similar bio- geography of rare and abundant bacteria in lakes on Yungui Plateau, China. Limnol Oceanogr 62:723-735

ㄴ.in X, McKinley J, Resch CT, Kaluzny R and others (2012) Spatial and temporal dynamics of the microbial community in the Hanford unconfined aquifer. ISME $\mathrm{J}$ 6: 1665-1676

Mezga K (2014) Natural hydrochemical background and dynamics of groundwater in Slovenia. PhD dissertation, University of Nova Gorica

*Mo Y, Zhang W, Yang J, Lin Y and others (2018) Biogeographic patterns of abundant and rare bacterioplankton in three subtropical bays resulting from selective and neutral processes. ISME J 12:2198-2210

Nelson D (2002) Natural variations in the composition of groundwater. Presented at Groundwater Foundation Annual Meeting, Drinking Water Program, 2002. Oregon Department of Human Services, Springfield, OR

*Niño-García JP, Ruiz-González C, del Giorgio PA (2016) Interactions between hydrology and water chemistry shape bacterioplankton biogeography across boreal freshwater networks. ISME J 10:1755-1766

Nyirabuhoro P, Liu M, Xiao P, Liu L and others (2020) Seasonal variability of conditionally rare taxa in the water column bacterioplankton community of subtropical reservoirs in China. Microb Ecol 80:14-26

Packard T (1971) The measurement of respiratory electron transport activity in marine phytoplankton. J Mar Res 29: 235-244

* Power JF, Carere CR, Lee CK, Wakerley GL and others (2018) Microbial biogeography of 925 geothermal springs in New Zealand. Nat Commun 9:2876

*Pronk M, Goldscheider N, Zopfi J (2009) Microbial communities in karst groundwater and their potential use for biomonitoring. Hydrogeol J 17:37-48

* Savio D, Stadler P, Reischer GH, Demeter K and others (2019) Spring water of an alpine karst aquifer is dominated by a taxonomically stable but discharge-responsive bacterial community. Front Microbiol 10:28

* Shabarova T, Widmer F, Pernthaler J (2013) Mass effects meet species sorting: transformations of microbial assemblages in epiphreatic subsurface karst water pools. Environ Microbiol 15:2476-2488

Shabarova T, Villiger J, Morenkov O, Niggemann J and others (2014) Bacterial community structure and dissolved organic matter in repeatedly flooded subsurface karst water pools. FEMS Microbiol Ecol 89:111-126

Simčič T, Mori N (2007) Intensity of mineralization in the hyporheic zone of the prealpine river Bača (West Slovenia). Hydrobiologia 586:221-234

* Sinreich M, Pronk M, Kozel R (2014) Microbiological monitoring and classification of karst springs. Environ Earth Sci 71:563-572

* Sirisena KA, Daughney CJ, Moreau M, Ryan KG, Chambers GK (2014) Relationships between molecular bacterial diversity and chemistry of groundwater in the Wairarapa Valley, New Zealand. N Z J Mar Freshw Res 48:524-539

Smart C, Worthington SRH (2004a) Karst water resources. In: Gunn J (ed) Encyclopedia of caves and karst science. Taylor and Francis, New York, NY, p 1033-1036

Smart C, Worthington SRH (2004b) Springs. In: Gunn J (ed) Encyclopedia of caves and karst science. Taylor and Francis, New York, NY, p 1495-1505

Smith CJ, Danilowicz BS, Clear AK, Costello FJ and others (2005) T-Align, a web-based tool for comparison of mul- 
tiple terminal restriction fragment length polymorphism profiles. FEMS Microbiol Ecol 54:375-380

Stegen JC, Lin X, Fredrickson JK, Chen X and others (2013) Quantifying community assembly processes and identifying features that impose them. ISME J 7:2069-2079

Stein H, Kellermann C, Schmidt SI, Brielmann H and others (2010) The potential use of fauna and bacteria as ecological indicators for the assessment of groundwater quality. J Environ Monit 12:242-254

Svoboda P, Lindström ES, Osman OA, Langenheder S (2018) Dispersal timing determines the importance of priority effects in bacterial communities. ISME J 12:644-646

ter Braak CJF, Šmilauer P (2012) Canoco reference manual and user's guide: software for ordination (version 5.0). Microcomputer Power, Ithaca, NY

Wang J, Soininen J, Zhang Y, Wang B and others (2011) Contrasting patterns in elevational diversity between microorganisms and macroorganisms. J Biogeogr 38:595-603

Wendland F, Blum A, Coetsiers M, Gorova R and others (2008) European aquifer typology: a practical framework for an overview of major groundwater composition at European scale. Environ Geol 55:77-85

Wilhartitz IC, Kirschner AK, Stadler H, Herndl GJ and oth-

Editorial responsibility: Paul del Giorgio,

Montreal, Quebec, Canada

Reviewed by: 3 anonymous referees ers (2009) Heterotrophic prokaryotic production in ultraoligotrophic alpine karst aquifers and ecological implications. FEMS Microbiol Ecol 68:287-299

Wilhartitz IC, Kirschner AK, Brussaard CP, Fischer UR and others (2013) Dynamics of natural prokaryotes, viruses, and heterotrophic nanoflagellates in alpine karstic groundwater. MicrobiologyOpen 2:633-643

Wilhelm L, Besemer K, Fragner L, Peter H and others (2015) Altitudinal patterns of diversity and functional traits of metabolically active microorganisms in stream biofilms. ISME J 9:2454-2464

* Yan L, Herrmann M, Kampe B, Lehmann R and others (2020) Environmental selection shapes the formation of near-surface groundwater microbiomes. Water Res 170: 115341

Zelaya AJ, Parker AE, Bailey KL, Zhang $\mathrm{P}$ and others (2019) High spatiotemporal variability of bacterial diversity over short time scales with unique hydrochemical associations within a shallow aquifer. Water Res 164:114917

* Zhou Y, Kellermann C, Griebler C (2012) Spatio-temporal patterns of microbial communities in a hydrologically dynamic pristine aquifer. FEMS Microbiol Ecol 81:230-242

Submitted: December 23, 2019

Accepted: December 10, 2020

Proofs received from author(s): February 23, 2021 